\title{
ANALISIS PENGARUH PENGGUNAAN SISTEM INFORMASI MANAJEMEN DAERAH (SIMDA) TERHADAP KUALITAS LAPORAN KEUANGAN PEMERINTAH DAERAH (Studi Kasus Dinas Pekerjaan Umum dan Penataan Ruang Provinsi Bengkulu)
}

\author{
Yesi Indian Ariska \\ Nia Indriasari \\ Fakultas Ekonomi Universitas Dehasen Bengkulu
}

\begin{abstract}
The purpose of this research aimed to test the influence of the implementation of region management information system on the quality of financial statement of regional government at Department of pekerjaan umum and penataan ruang province Bengkulu. The research population was 25 people who are the employees at this department. Research data were questionnaire as the primary data. The simple linear regression analysis was the technique of analysis of this research.Research result showed that the implementation of region management information system influenced significantly to the quality of financial statement of regional government at Department of of pekerjaan umum and penataan ruang province Bengkulu.. It was approved by the value of determinant coefficient which was $75.3 \%$. It meant that the quality of financial statement was influenced $75.3 \%$ by the region management information system.
\end{abstract}

Keywords: regional government, management information system, quality, inancial.

\section{PENDAHULUAN}

\section{Latar Belakang}

Pelaksanaan pembangunan daerah tidak terlepas dari keterpaduan dan sinergisitas seluruh elemen perangkat daerah yang ada di dalamnya. Dukungan dalam hal perencanaan dan pelaksanaan pembangunan daerah oleh pihak pemerintah pusat ke pemerintah daerah pun menjadi faktor penting keberhasilan pembangunan di suatu daerah. Salah satu langkah pendukung yang dilakukan oleh pemerintah pusat adalah memberikan kewenangan kepada daerah dalam penyelenggaraan otonomi daerah melalui Undang-Undang Nomor 32 Tahun 2004 tentang pemerintah daerah yang sebagimana telah diubah beberapa kali, terakhir dengan undang-undang No. 12 Tahun 2008 maka berbagai kelemahan dalam penyusunan dan pengelolaan anggaran pembangunan daerah diharapkan dapat disempurnakan. 
Otonomi daerah yang diatur dalam UU Nomor 32 Tahun 2004 memberi kewenangan pemerintah daerah dalam mengatur urusan rumah tangga daerah, menetapkan kebijakan, serta melakukan pembiayaan dan pertanggungjawaban keuangan sendiri. Di sisi lain tuntutan transparansi dan akuntabilitas dalam sistem pengelolaan keuangan daerah menuntut pemerintah daerah untuk lebih meningkatkan kinerja dalam pengelolaan keuangan daerah. Transparansi adalah memberikan informasi keuangan yang terbuka dan jujur kepada masyarakat berdasarkan pertimbangan bahwa masyarakat memiliki hak untuk mengetahui secara terbuka dan menyeluruh atas pertanggungjawaban pemerintah dalam pengelolaan sumber daya yang dipercayakan kepadanya dan ketaatannya pada peraturan perundang-undangan (KK,SAP,2005). Sedangkan akuntabilitas itu sendiri adalah mempertanggungjawabkan pengelolaan sumber daya serta pelaksanaan kebijakan yang dipercayakan kepada entitas pelaporan dalam mencapai tujuan yang telah ditetapkan secara periodik (KK,SAP,2005).

Berdasarkan PP No. 56 Tahun 2005 tentang Sistem Informasi Keuangan Daerah, pemerintah daerah berkewajiban mengembangkan dan memanfaatkan kemajuan teknologi informasi untuk meningkatkan kemampuan mengelola keuangan daerah, dan menyalurkan informasi keuangan daerah kepada publik. Salah satu bentuk pemanfaatan teknologi informasi adalah dengan penggunaan perangkat lunak sebagai alat bantu dalam sistem akuntansi dan keuangan daerah. Oleh karena itu, diperlukan sistem pengelolaan keuangan yang baik dalam rangka mengelola keuangan daerah secara akurat, tepat waktu, transparan, dan akuntabel.

Menurut Harahap (2010: 105) laporan keuangan menggambarkan kondisi keuangan dan hasil usaha suatu perusahaan/organisasi. Bagi para analis, laporan keuangan merupakan media yang paling penting untuk menilai prestasi dan kondisi ekonomis suatu perusahaan. Dilihat dari sisi manajemen perusahaan (pihak internal perusahaan), laporan keuangan merupakan alat pengendalian dan evaluasi kinerja manajerial dan organisasi. Sedangkan dari sisi pemakai eksternal, laporan keuangan merupakan salah satu bentuk pertanggungjawaban dan sebagai dasar untuk pengambilan keputusan. Beberapa peraturan perundang-undangan menyebutkan mengenai Laporan Keuangan Pemerintah Daerah (LKPD) yaitu dalam PP No. 58 Tahun 2005 tentang Pengelolaan Keuangan Daerah pasal 99 ayat 2, yang berbunyi: "penyelenggaraan akuntansi sebagaimana dimaksud ayat (1) merupakan pencatatan/penatausahaan atas traksaksi keuangan di lingkungan Satuan Kerangkat Pemerintah Daerah (SKPD) dan menyiapkan laporan keuangan sehubungan dengan pelaksanaan anggaran dan barang yang dikelolanya."

Sesuai dengan visi Badan Pengawasan Keuangan dan Pembangunan (BPKP) sebagai Auditor Presiden yang responsif, interaktif dan terpercaya untuk mewujudkan akuntabilitas keuangan Negara yang berkualitas dalam mentransformasikan manajemen pemerintahan menuju pemerintahan yang baik dan bersih serta sesuai amanat PP 60 tahun 2008 pasal 59 ayat (2) dan Inpres Nomor 4 Tahun 2011, BPKP dalam hal ini Deputi Pengawasan Bidang Penyelenggaraan Keuangan Daerah, memandang perlu untuk memfasilitasi Pemerintah Daerah dalam mempersiapkan aparatnya menghadapi perubahan, mendorong pelaksanaan tata kelola keuangan 
daerah sesuai dengan peraturan yang berlaku, efisien, efektif, transparan, akuntabel, dan auditabel. Hal ini penting guna meningkatkan kualitas Laporan Keuangan pemerintah daerah menuju terwujudnya good governance.

Sejalan dengan Rencana Pembangunan Jangka Panjang (RPJM) Tahun 2010-2014, dalam Renstra Tahun 2010-2014, Deputi Pengawasan Bidang Penyelenggaraan Keuangan Daerah telah menetapkan Pengembangan Sistem Informasi Manajemen Daerah sebagai kegiatan untuk mendukung capaian indikator kinerja " Meningkatnya Tingkat Opini Badan Pemeriksa Keuangan (BPK) terhadap LKPD".

Dinas Pekerjaan Umum dan Penataan Ruang Provinsi Bengkulu sebagai unit organisasi yang memberikan pelayanan pada masyarakat di bidang pekerjaan umum di bawah Pemerintah Daerah Provinsi Bengkulu yang terbentuk berdasarkan Peraturan Daerah (Perda) Nomor 05 Tahun 2007 tanggal 06 Juni 2007. Dinas Pekerjaan Umum dan Penataan Ruang mempunyai tugas membantu Gubernur dalam melaksanakan urusan otonomi daerah di bidang pekerjaan umum, yang di pimpin oleh seorang kepala yang berkedaulatan dibawah dan bertanggung jawab kepada Gubernur melalui Sekretaris Daerah.

Dinas Pekerjaan Umum dan Penataan Ruang Provinsi Bengkulu sudah memanfaatkan SIMDA dalam mengelola keuangan daerah serta menyusun laporan keuangan pemerintah daerah sejak tahun 2014 hingga sekarang. Walaupun secara umum banyak manfaat yang ditawarkan oleh penerapan SIMDA antara lain kecepatan pemrosesan transaksi dan penyiapan laporan, keakuratan perhitungan, penyimpanan data dalam jumlah besar, biaya pemrosesan yang lebih rendah, namun pengimplementasian SIMDA pada Dinas Pekerjaan Umum dan Penataan Ruang Provinsi Bengkulu juga memiliki kendala yang berkaitan dengan jaringan yang terganggu jika cuaca buruk, kondisi perangkat keras, perangkat lunak yang digunakan, pemutakhiran data serta terbatasnya sumber daya manusia yang ada menjadi penyebab buruknya pengelolaan keuangan.

Berdasarkan latar belakang masalah di atas, maka yang menjadi rumusan masalah penulis adalah seberapa besar pengaruh penerapan sistem informasi manajemen daerah (SIMDA) terhadap kualitas laporan keuangan pemerintah daerah pada Dinas Pekerjaan Umum dan Penataan Ruang Provinsi Bengkulu? Dengan memperhatikan rumusan masalah, maka tujuan dalam penulisan ini adalah untuk mengetahui besarnya pengaruh penerapan sistem informasi manajemen daerah (SIMDA) terhadap kualitas laporan keuangan pemerintah daerah pada Dinas Pekerjaan Umum dan Penataan Ruang Provinsi Bengkulu.

\section{TINJAUAN PUSTAKA}

\section{Sistem Informasi Manajemen Daerah (SIMDA)}

Secara umum, Sistem Informasi Manajemen Daerah (SIMDA) merupakan suatu sistem yang dapat membantu manajemen di dalam pengumpulan data, pengolahan 
serta analisis evaluasi data dan menyajikan ke dalam batas informasi yang bernilai dan akhirnya sampai pada pengambilan keputusan di mana informasi ini berguna untuk mendukung fungsi operasi manajemen (Machmud, Rizan. 2013).

Aplikasi Sistem Informasi Manajemen Daerah yang dikembangkan oleh Badan Pengawasan Keuangan dan Pembangunan (BPKP) dan dikenal dengan Aplikasi SIMDA merupakan salah satu produk dari teknologi sistem informasi yang digunakan oleh banyak pemerintah daerah di Indonesia dalam menyelenggarakan pengelolaan keuangan daerahnya. Menurut Djaja dalam (Budiman, Fuad dan Arza, Fefri Indra. 2013), Aplikasi SIMDA merupakan aplikasi database yang bertujuan untuk mempermudah pengelolaan keuangan daerah di lingkungan Organisasi Perangkat Daerah (OPD). Aplikasi SIMDA dikembangkan dengan memperhatikan dan mengimplementasikan Sistem Pengendalian Intern Pemerintah (SPIP). Oleh sebab itu pengendalian terhadap aplikasi menjadi suatu keharusan untuk menjadi pedoman bagi pemerintah daerah dalam mengimplementasikan aplikasi SIMDA untuk menghasilkan Laporan Keuangan Pemerintah Daerah (LKPD).

Output yang dihasilkan dari SIMDA Keuangan

1) Penganggaran

a. Rencana Kerja Anggaran (RKA)

b. Dokumen Pelaksanaan Anggaran (DPA)

c. Surat Penyediaan Dana (SPD)

2) Penatausahaan

a. Surat Permintaan Pembayaran (SPP)

b. Surat Perintah Membayar (SPM)

c. Surat Perintah Pencairan Dana (SP2D)

d. Surat Tanda Setoran (STS)

e. Register

f. Surat pengendalian lainnya.

3) Akuntansi dan Pelaporan

a. Jurnal

b. Buku besar

c. Buku pembantu

d. Laporan realisasi anggaran

e. Laporan arus kas

f. Neraca.

4) Program Aplikasi SIMDA Keuangan didukung dengan:

a. Buku manual sistem dan prosedur penganggaran

b. Buku manual sistem dan prosedur penatausahaan

c. Buku manual sistem dan prosedur akuntansi dan pelaporan

d. Buku pedoman pengoperasian aplikasi SIMDA Keuangan

\section{Kualitas Laporan Keuangan SKPD}

Halim(2007) menyatakan bahwa Keuangan daerah adalah semua hak dan kewajiban yang dapat dinilai dengan uang, juga segala sesuatu, baik berupa uang maupun barang, yang dapat dijadikan kekayaan daerah sepanjang belum dimiliki atau dikuasai oleh negara atau daerah yang lebih tinggi serta pihak-pihak lain sesuai peraturan perundangan yang berlaku. Pengertian ini tidak berbeda jauh dengan 
pengertian sebagaimana dijelaskan dalam Ketentuan Umum Peraturan Pemerintah No. 58 Tahun 2005 tentang Pengelolaan Keuangan Daerah di mana dalam peraturan tersebut dijelaskan pengertian Keuangan daerah sebagai semua hak dan kewajiban daerah dalam rangka penyelenggaraan pemerintah daerah yang dapat dinilai dengan uang termasuk di dalamnya segala bentuk kekayaan daerah tersebut. Berdasarkan Peraturan Pemerintah No. 71 Tahun 2010 dinyatakan adanya 8 Prinsip akuntansi dan pelaporan keuangan. Kedelapan prinsip tersebut adalah Basis akuntansi, Nilai historis, Realisasi, Substansi mengungguli bentuk formal, Periodisitas, Konsistensi, Pengungkapan lengkap, Penyajian wajar.

Bastian (2009: 94-96) menyatakan bahwa kualitas keuangan dapat diukur berdasarkan karakteristik diantaranya: dapat dipahami, relevan, materialitas, keandalan/reliabilitas, penyajian jujur, substansi mengungguli bentuk, netralitas, pertimbangan sehat, kelengkapan, dapat dibandingkan. Untuk menyusun laporan keuangan yang berkualitas maka penggunaan sistem informasi manajemen sangat diperlukan untuk mengurangi ketidaktelitian dan tingkat kesalahan dalam penyusunan laporan. Salah satu misi dalam penerapan SIMDA ialah meningkatkan kinerja pengelola keuangan di tiap-tiap SKPD dan menerapkan tata kelola pemerintahan yang baik dan bersih, bebas dari segala tindakan yang menjurus ke arah kolusi korupsi dan nepotisme.

Mitami (2013) melakukan penelitian untuk mengetahui gambaran mengenai penerapan SIMDA keuangan pada Dinas Pengelola Keuangan dan Aset Daerah (DPKAD) Pemerintah Kabupaten Pangkep. Menggunakan metode deskriptif. Hasil penelitian menunjukkan bahwa secara umum pegawai DPKAD Pangkep sudah memahami makna SIMDA keuangan serta gambaran pelaksanaannya yang berkaitan dengan input dan output datanya. Budiyanto (2013) dalam penelitiannya bertujuan untuk mengetahui bagaimana SIMDA Keuangan sebagai Sistem Informasi Akuntansi Daerah dapat mempermudah tugas pelaporan dan pengelolaan keuangan Daerah. Menggunakan metode deskriptif. Hasil penelitian menunjukan telah diimplementasikan dengan cukup baik, Namun terdapat kekurangan yakni Fungsi akuntansi dalam aplikasi SIMDA Keuangan belum dapat diaplikasikan secara maksimal karena fungsi menu pembukuan didisable oleh admin SIMDA Keuangan dan hanya dapat dilakukan oleh admin/operator Dinas Pekerjaan Umum dan Penataan Ruang Provinsi Bengkulu.

\section{METODE PENELITIAN}

Jenis penelitian dalam penulisan ini menggunakan metode survei. Survei dilakukan terhadap sekumpulan objek yang biasanya cukup banyak dalam jangka waktu tertentu, tetapi tidak seluruh objek diteliti melainkan melalui perwakilan dari seluruh objek tertentu (Notoatmodjo, 2012:35). Adapun metode pengumpulan data yang digunakan dalam penelitian ini dilakukan dengan menyebarkan kuesioner guna memperoleh data primer. Menurut Sugiyono (2012: 199) kuesioner adalah 
teknik pengumpulan data yang dilakukan dengan cara memberi seperangkat pertanyaan atau pernyataan tertulis kepada reponden untuk dijawabnya.

Analisis data adalah cara mengelola data yang terkumpul kemudian dapat memberikan interpretasi. Hasil pengolahan data ini digunakan untuk menunjukkan masalah yang telah dirumuskan. Analisis dat yang digunakan dalam penelitian ini adalah uji Validitas dan uji Reliabilitas

\section{Uji Validitas}

Validitas adalah suatu ukuran yang menunjukkan tingkat keabsahan dan kevalidan suatu alat ukur atau instrument penelitian. Validitas menunjukkan seberapa baik suatu instrument yang dibuat mengukur konsep tertentu yang ingin diukur (Sekaran, 2006). Suatu pertanyaan dikatakan valid dan dapat mengukur variabel penelitian yang dimaksudjika nilai koefisien validitasnya lebih dari atau sama dengan 0,3 (Azwar, 2000: 14).

\section{Uji Reliabilitas}

Uji Reabilitas dilakukan terhadap alat ukur berupa kuesioner yang digunakan dalam penelitian ini pada variabel sistem informasi manejemen daerah terhadap variabel kualitas laporan keuangan daerah. Uji reliabilitas variabel penelitian ini dilakukan dengan menggunakan bantuan alat pengolahan data software SPSS Ver 19.

\section{Method Of Succesive Interval (MSI)}

Data yang diperoleh melalui kuesioner masih berskala ukur ordinal. Sedangkan salah satu syarat dalam analisis regresi linear sederhana maupun berganda adalah data harus berskala ukur interval. Dengan demikian sebelum diolah lebih lanjut dengan menggunakan analisis regresi, data yang diperoleh terlebih dahulu dinaikkan atau diubah menjadi skala interval. Metode untuk menaikkan pengukuran data dari ordinal ke interval tersebut dinamakan method of succesive interval (MSI).

\section{Pengujian Hipotesis}

\section{Pengujian Asumsi Normalitas}

Uji normalitas untuk mengetahui apakah variabel dependen, independen atau keduanya berdistribusi normal, mendekati normal atau tidak (Umar, 2011:181). Model regresi yang baik hendaknya berdistribusi normal atau mendekati normal.

\section{Regresi Linear Sederhana}

Menurut Sugiyono (2012: 270) regresi sederhana didasarkan pada hubungan fungsional ataupun kausal satu variabel independen dengan satu variabel dependen. Analisis regresi dalam hal ini digunakan untuk melihat seberapa besar pengaruh 
Sistem Informasi Manajemen Daerah (SIMDA) Keuangan terhadap kualitas laporan keuangan Dinas Pekerjaan Umum dan penataan Ruang Provinsi Bengkulu.

\section{Uji Koefisien Determinan $\mathbf{R}^{2}$}

Untuk mengukur besarnya proporsi atau besarnya pengaruh variabel independen terhadap variabel dependen maka dilakukan pengujian koefisien determinan. Koefisien determinan berkisar antara nol sampai dengan satu $(0 \leq \mathrm{R} 2 \leq 1)$. Hal ini berarti R2 = 0 menunjukkan tidak adanya pengaruh antara variabel independen terhadap variabel dependen, bila R2 semakin besar mendekati 1, menunjukkan semakin kuatnya pengaruh variabel independen terhadap variabel dependen dan R2 semakin kecil mendekati nol maka dapat dikatakan semakin kecilnya pengaruh variabel independen terhadap variabel dependen.

\section{HASIL DAN PEMBAHASAN}

\section{Uji Validitas dan Reliabilitas Data}

Dari 25 pertanyaan yang digunakan untuk mengukur hal-hal yang berkaitan dengan variabel sistem informasi manajemen daerah, sebanyak 19 pertanyaan yang telah memiliki koefisien korelasi $>0.3$. Sedangkan enam pertanyaan lainnya memiliki koefisien validitas dibawah 0.3. Untuk koefisien reliabilitas adalah sebesar 0,783.Nilai koefisien reliabilitas ini menunjukkan hasil pengukuran yang dihasilkan oleh instrumen yang digunakan menunjukkan konsistensi yang sudah cukup baik karena telah memenuhi standar minimal koefisien reliabilitas yang disyaratkan. Berdasarkan hasil pengujian validitas dan reliabilitas ini kemudian dilakukan perbaikan terhadap item pertanyaan yang masih lemah sehingga hasil pengukuran yang akan diperoleh nanti dapat di pertanggungjawab kan.

Dari 12 pertanyaan yang digunakan untuk mengukur variabel kualitas laporan keuangan, sebanyak 10 pertanyaan telah memiliki koefisien korelasi $>0.3$. Pernyataan yang memiliki koeifisen validitas dibawah 0.3 sebanyak 2 pernyataan. Sedangkan untuk koefisien reliabilitas adalah sebesar 0.491. Nilai koefisien reliabilitas ini masih dibawah standar yang ditetapkan yakni sebesar 0,5. Berdasarkan hasil pengujian validitas dan reliabilitas ini kemudian dilakukan perbaikan dan penyempurnaan instrumen yang digunakan sebelum disebarkan kepada responden sasaran. Perbaikan yang dilakukan meliputi struktur kalimat yang digunakan, menghilangkan kata/kalimat yang dapat menimbulkan ambiguitas (multi tafsir), serta perbaikan pilihan jawaban. 


\section{Uji Normalitas Data}

Berdasarkan Gambar 1. dapat dilihat bahwa titik-titik menyebar di sekitar garis diagonal dan penyebarannya mengikuti arah garis diagonal. Dengan demikian dapat dinyatakan bahwa penyebaran data mendekati normal atau telah memenuhi asumsi normalitas.

Gambar 1.

\section{Hasil Pengujian Normalitas Data}

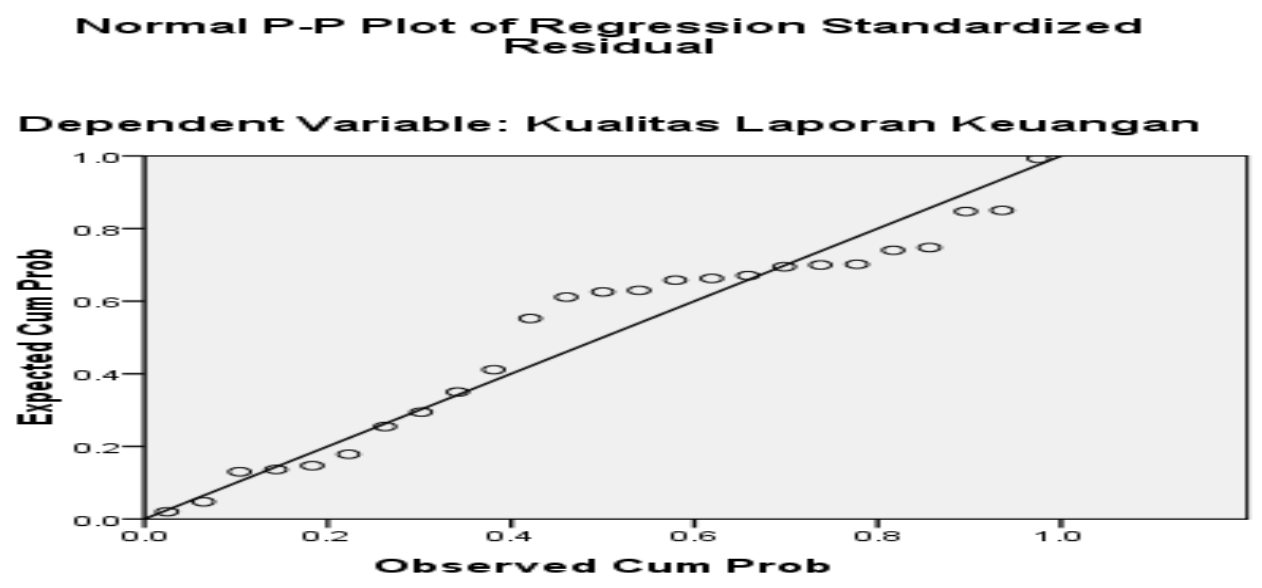

Sumber: Data Diolah, 2017

\section{Hasil Analisis Regresi}

Untuk mengetahui bagaimana pengaruh Sistem Informasi Manajemen Daerah terhadap kualitas laporan keuangan di dinas pekerjaan umum dan penataan ruang Provinsi Bengkulu dilakukan dengan menggunakan analisis regresi. Hasil analisis regresi dengan menggunakan bantuan SPSS adalah sebagai berikut:

\section{Tabel 1: Hasil Analisis Regresi}

Coefficients $^{\mathrm{s}}$

\begin{tabular}{|c|c|c|c|c|c|c|}
\hline \multirow[b]{2}{*}{ Made } & & \multicolumn{2}{|c|}{ Unstandardized Coefficients } & $\begin{array}{l}\text { Standardized } \\
\text { Coefficients }\end{array}$ & \multirow[b]{2}{*}{$t$} & \multirow[b]{2}{*}{ Sig. } \\
\hline & & B & Std. Error & Beta & & \\
\hline 1 & (Constant) & .607 & .449 & & 1.353 & .189 \\
\hline & $\begin{array}{l}\text { Penerapan Sistem } \\
\text { Informasi Manajemen } \\
\text { Daerah }\end{array}$ & .665 & .170 & .633 & 3.917 & .001 \\
\hline
\end{tabular}

a. Dependent Variable: Kualitas Laporan Keuangan

Sumber: Data Diolah, 2017 
Berdasarkan hasil analisis diatas maka model regresi antara penerapan sistem informasi manajemen daerah dengan kualitas laporan keuangan di dinas pekerjaan umum dan penataan ruang provinsi Bengkulu adalah sebagai berikut:

\section{$\underline{Y=0,607+0,665 X}$}

Dari model diatas diketahui koefisien regresi untuk variabel $\mathrm{X}$ (penerapan sistem informasi manajemen daerah) bernilai positif sebesar 0,665 . Koefisien regresi yang positif ini menunjukkan bahwa sistem informasi manajemen daerah mempunyai pengaruh yang positif terhadap kualitas laporan keuangan. Semakin baik penerapan sistem informasi manajemen daerah dalam pelaporan keuangan maka kualitas laporan keuangan yang dihasilkan oleh pemerintah daerah juga akan semakin baik pula.

\section{Pengujian Model Regresi}

Analisis regresi selain digunakan untuk melihat pengaruh juga digunakan untuk membuat model prediksi dari variabel-variabel yang diamati. Untuk itu sebelum digunakan dalam pengambilan keputusan, model yang diperoleh terlebih dahulu harus diuji kebaikannya (goodness of fit).

Tabel 2

Hasil Pengujian Model Regresi

\begin{tabular}{|ll|r|r|r|r|l|}
\hline \multicolumn{1}{|c|}{ Model } & Sum of Square & Df & Mean Square & F & Sig. \\
\hline 1 Regression & 11.344 & 1 & 11.344 & 115.890 & $.000^{\mathrm{a}}$ \\
Residual & 3.720 & 38 & .098 & & \\
Total & 15.064 & 39 & & & \\
\hline
\end{tabular}

Sumber: Data Olahan, 2017

Dari hasil di atas didapat nilai F-hitung sebesar 115,89. Adapun nilai Ftabel pada tingkat signifikansi $5 \%$ dan derajat bebas pembilang (df1) sebesar $\mathrm{k}=1$ dan derajat bebas penyebut (df2) sebesar N-k-1 = 40-1-1 = 38 adalah sebesar 4,098. Jika kedua nilai F ini dibandingkan, maka nilai F-hitung yang diperoleh jauh lebih besar F-tabel sehingga Ho ditolak. Dengan demikian dapat disimpulkan bahwa model regresi yang dihasilkan sudah sesuai dengan data. 


\section{Pengujian Hipotesis}

Setelah pengujian model dilakukan selanjutnya akan dilaksanakan pengujian signfikansi pengaruh dari variabel X (sistem informasi manajemen daerah) terhadap kualitas laporan keuangan.

Dari hasil analisis sebelumnya diketahui nilai t-hitung untuk variabel sistem informasi manajemen daerah adalah sebesar 10,765. Sedangkan nilai tabel pada tingkat signfikansi 5\% dan derajat bebas 38 sebesar 2,024. Jika dibandingkan dengan nilai t-hitung yang diperoleh maka nilai t-hitung yang diperoleh masih jauh lebih besar dari nilai t-tabel sehingga Ho ditolak. Dengan demikian dapat disimpulkan terdapat pengaruh yang signifikan dari penerapan sistem informasi manajemen daerah terhadap kualitas laporan keuangan di dinas pekerjaan umum dan penataan ruang provinsi Bengkulu dan pengaruhnya bersifat positif. Semakin baik sistem informasi manajemen daerah maka kualitas laporan keuangan juga akan semakin meningkat.

\section{Interpretasi Koefisien Determinasi}

Nilai koefisien determinasi untuk model regresi antara sistem informasi manajemen daerah dengan kualitas laporan keuangan yang diperoleh dengan menggunakan bantuan SPSS adalah sebagai berikut:

Tabel 3

Interpretasi Koefisien Determinasi

\begin{tabular}{|l|r|}
\hline \multirow{2}{*}{} & \multicolumn{2}{|c|}{ Model } \\
\cline { 2 - 2 } & \multicolumn{2}{|c|}{ I } \\
\hline R & .868 \\
Adjusted R Square & .753 \\
Std. Error Of the & .747 \\
\hline
\end{tabular}

Sumber: Data Olahan, 2017

Berdasarkan hasil estimasi diatas diperoleh nilai koefisien determinasi R2 sebesar 0,753 . Nilai ini berarti bahwa sebesar $75,3 \%$ kualitas laporan keuangan di dinas pekerjaan umum dan penataan ruang provinsi Bengkulu dipengaruhi oleh penerapan sistem informasi manajemen daerah, sedangkan sisanya sebesar $24,7 \%$ dipengaruhi oleh variabel lain diluar model. 


\section{Pengaruh Penerapan Sistem Informasi Manajemen Daerah Terhadap Kualitas Laporan Keuangan Pemerintah Daerah}

Laporan keuangan merupakan wujud pertanggung jawaban keuangan daerah dan merupakan tanggungjawab atas akuntabilitas publik serta merupakan salah satu ukuran keberhasilan (kinerja) pemerintah daerah. Laporan keuangan yang disajikan oleh pemerintah harus berkualitas, yakni yang memenuhi karakteristik kualitatif yaitu, andal, relevan, dapat dibandingkan dan dapat dipercaya.

Dalam rangka untuk meningkatkan kualitas laporan keuangan pemerintah daerah di Indonesia, telah banyak upaya yang dilakukan oleh Pemerintah Pusat. Salah satu upaya yang telah dilakukan adalah dengan menerbitkan Peraturan Pemerintah No. 56 Tahun 2005 tentang sistem informasi keuangan daerah, pemerintah daerah berkewajiban mengembangkan dan memanfaatkan kemajuan teknologi informasi untuk meningkatkan kemampuan mengelola keuangan daerah, dan menyalurkan informasi keuangan daerah kepada publik. Salah satu bentuk pemanfaatan teknologi informasi adalah dengan penggunaan perangkat lunak sebagai alat bantu dalam sistem akuntansi dan keuangan daerah. Oleh karena itu, diperlukan sistem pengelolaan keuangan yang baik dalam rangka mengelola keuangan daerah secara akurat, tepat waktu, transparan, dan akuntabel. Selanjutnya, Peraturan Pemerintah (PP) No. 24 tahun 2005 tentang Standar Akuntansi Pemerintah (SAP) yang kemudian disempurnakan lagi dengan terbitnya PP No. 71 tahun 2010. Dalam PP tersebut secara jelas dinyatakan bahwa "Standar Akuntansi Pemerintah, yang selanjutnya disingkat SAP, adalah prinsip-prinsip akuntansi yang diterapkan dalam menyusun dan menyajikan laporan keuangan pemerintah". Pemerintah mengharapkan dengan diterbitkannya Peraturan Pemerintah tentang SAP diatas dapat membantu para pengelolaan keuangan untuk menghasilkan laporan keuangan yang berkualitas sehingga dapat memenuhi akuntabilitas publik.

Dari hasil analisis yang dilakukan sebelumnya diketahui bahwa terdapat pengaruh yang positif dari penerapan sistem informasi manajemen daerah terhadap kualitas laporan keuangan di Dinas Pekerjaan Umum dan Penataan Ruang provinsi Bengkulu. Hal ini didasarkan dari hasil pengujian dengan menggunakan uji-t yang memberikan hasil yang signifikan pada tingkat kepercayaan 95\%. Koefisien regresi yang positif menunjukkan bahwa jika penerapan sistem informasi manajemen daerah semakin baik maka akan diikuti dengan peningkatan kualitas laporan keuangan di Dinas Pekerjaan Umum dan Penataan Ruang Provinsi Bengkulu.

Adapun besar pengaruh dari sistem informasi manajemen daerah terhadap kualitas laporan keuangan adalah sebesar 75,3\% sedangkan sisanya sebesar 24,7\% dipengaruhi oleh variabel lain, variabel tersebut antara lain sistem pengendalian intern dan kualitas sumber daya manusia. Dari hasil koefisien determinasi ini 
terlihat bahwa walaupun pengaruh dari penerapan sistem informasi manajemen daerah sudah cukup besar, namun pengaruh dari variabel lain juga cukup dominan. Ini berarti bahwa selain sistem informasi manajemen daerah, masih banyak hal lain yang mempengaruhi kualitas laporan keuangan. Sehingga kedepannya diperlukan pengawasan yang lebih ketat dan sosialisasi yang lebih intens agar kualitas laporan keuangan Dinas Pekerjaan Umum dan Penataan Ruang Provinsi Bengkulu dapat lebih ditingkatkan.

\section{KESIMPULAN DAN SARAN}

\section{Kesimpulan}

Berdasarkan hasil analisis regresi untuk variabel X (penerapan sistem informasi manajemen daerah) bernilai positif sebesar 0,665. Koefisien regresi yang positif ini menunjukkan bahwa SIMDA mempunyai pengaruh yang positif terhadap kualitas laporan keuangan. Berdasarkan hasil estimasi diperoleh nilai koefisien determinasi R2 sebesar 0,753. Nilai ini berarti bahwa sebesar 75,3\% kualitas laporan keuangan di Dinas Pekerjaan Umum dan Penataan Ruang Provinsi Bengkulu dipengaruhi oleh penerapan Sistem Informasi Manajemen Daerah, sedangkan sisanya sebesar 24,7\% dipengaruhi oleh variabel lain diluar model, variabel lain tersebut antara lain sistem pengendalian intern dan kualitas sumber daya manusia. Maka dapat dikatakan bahwa semakin baik Sistem Informasi Manajemen Daerah maka kualitas laporan keuangan juga akan semakin meningkat.

\section{Saran}

Berdasarkan simpulan penelitian ini, penulis memberikan saran bagi Pihak Dinas Pekerjaan Umum dan Penataan Ruang Provinsi Bengkulu sebaiknya lebih memperhatikan kualitas jaringan SIMDA dan kualitas SDM dengan mengadakan bimbingan teknis dalam mengelola SIMDA agar kedepannya SIMDA di Dinas Pekerjaan Umum dan Penataan Ruang Provinsi Bengkulu tidak akan mengalami hambatan dan kendala dalam penyusunan laporan. Untuk penelitian selanjutnya diharapkan dapat memperhatikan beberapa variabel lain selain penerapam SIMDA yang dapat mempengaruhi kualitas laporan keuangan pemerintah daerah yang tidak diteliti dalam penelitian ini. 


\section{DAFTAR PUSTAKA}

Azwar, Saifuddin. 2000. Reliabilitas dan Validitas. Yogyakarta : Pustaka Pelajar.

Badan Pengawasan Keuangan dan Pembangunan. 2013. Pengenalan Sistem Informasi Manajemen Daerah (SIMDA). http://www.bpkp.go.id/sakd/konten/333/Versi-2.1.bpkp. (Diakses 20 Mei 2017).

Budiman, Fuad dan Arza, Fefri Indra. 2013. Pendekatan Technology Acceptance Model dalam Kesuksesan Implementasi Sistem Informasi Manajemen Daerah. Jurnal WRA, 1(1), 87-110

Budiyanto, Nur. 2013. Evaluasi Keberhasilan Penggunaan Sistem Informasi Manajemen Keuangan Daerah Ditinjau Dari Opini BPK-RI. Tesis. Program Pascasarjana Fakultas Teknik Universitas Gadjah Mada: Yogyakarta. Dipublikasikan. Melalui http://www.google.com (Diakses 18 Maret 2017).

Halim, Abdul. 2007. Akuntansi Keuangan Daerah. Jakarta: Salemba Empat.

Halim, Abdul. 2007. Pengelolaan Keuangan Daerah. Yogyakarta: UPP STIM YKPN.

Harahap, Sofyan Syafri. 2010. Analisis Kritis atas Laporan Keuangan. Jakarta: Rajawali Pres.

Indra Bastian. 2009. Akutansi untuk LSM dan Partai Politik. Jakarta: Erlangga

Mitami, Dian. 2013. Analisis Penerapan Informasi Manajemen Daerah Keuangan Pada

Pemerintah Daerah Kabupaten Pangkep. E-Journal Unhas. http://repository.unhas.ac.id/handle/123456789/9950. Diakses Juni 2017. Hal. 1-73 Notoatmodjo, Soekidjo. 2012. Metodologi Penelitian Kesehatan. Jakarta : Rineka Cipta.

Machmud, Rizan. 2013. Hubungan Sistem Informasi Manajemen dan Pelayanan dengan Kinerja Pegawai pada Rutan Makassar. Jurnal Capacity STIE AMKOP Makassar. 9(1), 78-85

Ridwan. 2009. Pengaruh Penerapan Aplikasi Sistem Informasi Manajemen Daerah (SIMDA) Keuangan terhadap Kualitas Laporan Keuangan Pemerintah Daerah. $\quad$ Skripsi. Universitas Padjajaran: Bandung. Melalui http://www.google.com (Diakses 24 Maret 2017).

Sugiyono, 2012. Metode Penelitian Bisnis, Cetakan Ke-16. Bandung : CV. Alfabeta.

Supranto, J. 2000. Statistika Teori dan Aplikasi, Edisi Enam. Jakarta : Erlangga.

Umar, Husein. 2011. Metode Penelitian untuk Skripsi dan Tesis Bisnis, Edisi I. Jakarta: Rajawali Pers.

Peraturan Pemerintah Nomor 56 Tahun 2005 tentang Sistem Informasi Keuangan Daerah.

-71 Tahun 2010 tentang Standar Akuntansi Pemerintah.

Peraturan Mentri Dalam Negeri Nomor 4 Tahun 2008 tentang Perencanaan Review LKPD.

Undang-undang Nomor 32 Tahun 2004 tentang Pemerintah Daerah. 